11. Привало О.Е. Оптимизация А и Е-витаминного питания молочного скота в современных системах кормления: автореф. дис. ... д-ра с.-х. наук. - М., 1987. - 24 с.

12. Резниченко Л.В., Савченко Т.Г., Бабенко О.О. Роль бета-каротина в организме животных // Зоотехния. - 2007. - № 11. - С. 8-9.

13. Рекомендации по использованию гидропонических зеленых кормов в рационах крупного рогатого скота / А.А. Васильев [и др.]. - Саратов, 2013. - 35 с.

Валошин Андрей Владимирович, канд. с.-х. наук, доцент кафедры «Технология производства и переработ- ки продукции животноводства», Мордовский государственный университет имени Н.П. Огарева. Россия.

Крисанов Александр Федорович, $\partial-p c .-x$. наук, проф. кафедры «Технология производства и переработки продукции животноводства», Мордовский государственный университет имени Н.П. Огарева. Россия.

430904, г. Саранск, пос. Ялга, ул. Российская, 31.

Тел.: (8342) 25-40-02.

Ключевые слова: бычки; сухой жом; жомовые грануль; витамин А; «МИКРОВИТ»; рационы; перевариMосmb.

\title{
INFLUENCE OF VITAMIN A AS A SYNTHETIC PREPARATION “MICROVIT" ON THE DIGESTIBILITY OF BASIC NUTRIENTS OF FODDER BY BULL-CALVES AT THEIR FEEDING WITH THE USE OF FRAGRANCE GRANULES
}

Valoshin Andrey Vladimirovich, Candidate of Agricultural Sciences, Associate Professor of the chair "Technology for the Production and Processing of Livestock Products", Mordovia State University named after N.P. Ogarev. Russia.

Krisanov Aleksandr Fedorovich, Doctor of Agricultural Sciences, Professor of the chair "Technology for the Production and Processing of Livestock Products", Mordovia State University named after N.P. Ogarev. Russia.

Keywords: bull-calves; dry pulp; pulp granules; Vitamin A; Microvit; rations; digestibility.

They are given data of physiological action of vitamin $A$ in different doses (in the form of its supplement - the pharmacological preparation "Microvit") when introduced into diets with dry pulp on the digestibility of the main nutrients of fodder by bull-calves in the middle of the feeding cycle. The optimal dose of vitamin A was established. It is 230 IU per 1 head per day, which is $20 \%$ more than the recommended norm calculated for carotene. In this case, the digestibility of dry matter significantly increases by $3.3 \%$, of organic one - by $2.7 \%$, protein - by $3.0 \%$, fiber - by $3.2 \%$. There was also a slight tendency towards an increase in the digestibility of fat and nitrogen-free extractive substances by 1.8 and $3.0 \%$, respectively.

\section{ВЛИЯНИЕ БИОДОБАВОК НА БИОХИМИЧЕСКИЕ ПОКАЗАТЕЛИ КРОВИ ПОРОСЯТ В ПЕРИОД ДОРАЩИВАНИЯ}

\author{
ПОЛОЗЮК Ольга Николаевна, Донской государственный аграрный университет \\ ЛАПИНА Татьяна Ивановна, ФГБУ «Ростовский референтный изентр Россельхознадзора»
}

Установлено, что биологически активные вещества необходимо применять в определенные периоды жизни поросят и в определенных дозировках. Применение пробиотика на основе бактерий рода Васіllus штаммов бацилл В. subtillus и В. amyloliquefaciens из расчета 20 на 1 голову с 8-го по 28-й и с 35-го по 90-й дни жизни вызвало «перенаселение» организма молодняка бактериями, ито привело к угнетению биохимических показателей крови. Это проявилось в снижении общего количества белка и $\gamma$ - глобулиновой фракции, повышении уровня глюкозы в крови поросят на 2,1 и 2,6 ммоль/л, следовательно, привело к нарушению белкового и углеводного обмена. Использование пробиотика из расчета 5 г на 1 голову с 8-го по 15-й денъ, 10 г - с 24-го по 28-й и с 35-го по 90-й денъ жизни (7 дней препарат получали, 5 дней перерыв) позволило улучшить окислительно-восстановительные процессы организма.

Введение. Биохимическим показателям принадлежит важное место в ряде механизмов, с помощью которых происходит приспособление организма животного к воздействию новых стресс-факторов окружающей среды в ходе его онтогенеза. Одновременно с адаптацией происходит становление резистентности, ее неспецифического механизма, что выражается в изменении показателей. Как результат происходит полная перестройка организма для дальнейшего поддержания нормального его функционирования.

Для повышения устойчивости организма ко всему для них генетически чужеродному необходимо использовать средства, мягко действующие на него. Таковыми и являются биологически активные вещества, активно применяемые в вете- ринарии, в частности кишечные полипептиды, пробиотики, пребиотики, органические кислоты и др. $[1,2,3,6]$. В ветеринарии они применяются недавно, поэтому мало данных об их влиянии на организм животных в различных дозировках $[4,5]$. В связи с этим очевидна актуальность исследования биохимических показателей крови поросят в постнатальном онтогенезе при использовании различных схем применения биологически активных веществ.

Цель работы - выявление особенностей становления морфологического и биохимического статуса организма поросят в постнатальном онтогенезе, обоснование возможности их коррекции при использовании биологически активных веществ в зависимости от дозировки. 
Методика исследований. Исследования проводили в ООО «Русская свинина, Развильное» Песчанокопского района Ростовской области в зимне-весенний период. Животные находились в одинаковых условиях содержания и кормления. Для выявления влияния различных доз пробиотика на основе бактерий рода Bacillus штаммов бацилл B. subtillus и B. amyloliquefaciens с четко выраженной ферментативной и антагонистической активностью были сформированы две опытные и одна контрольная группы поросят-сосунов $1 / 2 К Б+1 / 2 Л$.

В 1-й опытной группе с 8-го по 15-й день после рождения выпаивали по 15 г пробиотика, предварительно растворив его в воде; с 15-го по 28-й - 20 г на 1 голову. Во 2-й опытной группе пробиотик выпаивали из расчета 5 г на 1 голову с 8-го по 15-й день, а с 24-го по 28-й день по 10 г, предварительно растворив в воде. В 28-дневном возрасте провели отъем поросят и перевели молодняк в корпус доращивания. Здесь поросята 1-й опытной группы с 35-го по 90-й день жизни получали пробиотик в по 20 г на 1 голову, а 2-й опытной группы - по 10 г на 1 голову: 7 дней давали, 5 дней перерыв. В 90-дневном возрасте проводили морфологические и биохимические исследования крови поросят, находящихся в эксперименте.

Биохимические исследования крови проводили на автоматическом анализаторе Idexx в лаборатории клиники скорой ветеринарной помощи г. Ростова. Биометрическую обработку результатов исследований осуществляли по стандартным методикам.

Результаты исследований. Анализ результатов морфологических показателей крови поросят в 90-дневном возрасте (табл. 1) показал, что содержание эритроцитов, лейкоцитов и количество гемоглобина было в пределах референтных значений. Однако у поросят 2-й опытной группы эритроцитов в крови было больше, чем в 1-й опытной и контрольной группах, на 22,8 $(P>0,99)$ и $12,9 \%$ соответственно.

Сложный механизм окислительно-восстановительных процессов в организме тесно связан с гемоглобином. Он является дыхательным пигментом крови, участвующим в транспорте кислорода и углекислоты, выполняющим также буферные функции (поддержание $\mathrm{pH}$ ). При исследовании крови установлено, что количество гемоглобина у животных было в пределах физиологической нормы. Однако поросята 2-й опытной группы превосходили сверстников 1-й опытной и контрольной групп по содержанию гемоглобина в 90-дневном возрасте на $26,6 \%$ $(P>0,999)$ и $10,8 \%(P>0,95)$.

Количество лейкоцитов в крови характеризует состояние обменных процессов в организме и иммунный статус животных. По содержанию лейкоцитов в крови поросята 2-й опытной группы также превосходили 1-ю и контрольную группы поросят на $17,5 \%(P>0,99)$ и 11,0 \% $(P>0,95)$. Это означает, что защитный потенциал у поросят 2-й опытной группы выше, чем в 1-й опытной и контрольной группах.

Об общем состоянии организма и об уровне метаболических процессов можно судить по ряду биохимических показателей крови. Так, жизненно необходимыми компонентами плазмы являются белки. Многие авторы $[2,5,6]$ считают, что существует динамическое равновесие между белками крови и белками других тканей. Сывороточные белки рассматриваются как исходный материалдля образования специфических белков различных тканей и выравнивания процессов обмена белков в тканях. В поддержании онкотического давления, уровня солей желчных кислот, триптофана, билирубина, транспорте кальция важную роль играют альбумины. Гормоны (тироксин, инсулин), а также железо и некоторые витамины транспортируются $\alpha$ - и $\beta$-глобулинами. В иммунном ответе участвуют $\gamma$-глобулины.

Проанализировав данные, представленные в табл. 2, нами установлено, что у поросят, находящихся под наблюдением, существенные изменения в изучаемый период отмечали в протеинограмме. Так, количество общего белка, альбуминов и глобулинов более активно увеличивается у подсвинков 2-й опытной группы. Beроятнее всего это происходит за счет того, что у поросят этой группы количество полезной микрофлоры достигало уровня, способствующего повышению обменных процессов в организме.

При исследовании белковых фракций количество $\alpha$ - и $\beta$-глобулинов существенных различий не имело. Содержание общего белка в сыворотке крови у поросят 2-й опытной группы, получавших к основному рациону биологически активные вещества, было выше на 7,8 г/л $(P>0,99)$ и 6,3 г/л $(P>0,95)$, чем у сверстников 1-й опытной и контрольной групп. Прирост общего белка происходил за счет $\gamma$-глобулинов, которые за исследуемый период увеличились во 2 -й опытной группе на $10,1 \%(P>0,99)$ и $6,0 \%(P>0,95)$ по сравнению с 1-й опытной и контрольной группами. Увеличение количества $\gamma$-глобулинов в сыворотке крови у поросят 2-й опытной группы способствовало увеличению

Таблица 1

Морфологические показатели крови поросят

\begin{tabular}{|c|c|c|c|}
\hline Группа & WBC, $10^{9} /$ л & $\mathrm{RBC}, 10^{12} /$ л & $\mathrm{Hb}$, Г/л \\
\hline 1 -я опытная & $6,14 \pm 0,18$ & $4,82 \pm 0,16^{* *}$ & $98,46 \pm 1,18^{* * *}$ \\
\hline 2-я опытная & $7,22 \pm 0,20$ & $5,92 \pm 0,21$ & $124,64 \pm 2,04$ \\
\hline Контрольная & $6,50 \pm 0,12$ & $5,24 \pm 0,19$ & $112,48 \pm 1,46^{*}$ \\
\hline
\end{tabular}

* $P>0,95 ;$ ** $P>0,99 ; * * * P>0,999$ (здесь и далее). 
Биохимические показатели крови поросят в 90-дневном возрасте

\begin{tabular}{|c|c|c|c|c|c|c|}
\hline \multirow[b]{2}{*}{ Группа } & \multirow{2}{*}{$\begin{array}{c}\text { Общий } \\
\text { белок, г/л }\end{array}$} & \multirow{2}{*}{$\begin{array}{c}\text { Альбу- } \\
\text { мины, \% }\end{array}$} & \multicolumn{3}{|c|}{ Глобулины,\% } & \multirow{2}{*}{$\begin{array}{l}\text { Глюкоза, } \\
\text { ммоль/л }\end{array}$} \\
\hline & & & $\alpha$ & $\beta$ & $\gamma$ & \\
\hline 1-я опытная & $70,5 \pm 1,2^{* *}$ & $25,6 \pm 0,8$ & $15,8 \pm 0,3$ & $12,8 \pm 0,6$ & $16,3 \pm 0,8^{* *}$ & $5,8 \pm 0,3$ \\
\hline 2-я опытная & $78,3 \pm 1,6$ & $28,7 \pm 1,2$ & $13,4 \pm 0,4$ & $8,9 \pm 0,8$ & $26,4 \pm 0,4$ & $3,7 \pm 0,4^{*}$ \\
\hline Контрольная & $72,0 \pm 1,4^{*}$ & $28,5 \pm 1,4$ & $12,9 \pm 0,5$ & $10,2 \pm 0,4$ & $20,4 \pm 0,6^{*}$ & $3,2 \pm 0,2^{* *}$ \\
\hline
\end{tabular}

напряженности иммунитета организма молодняка.

Применение биологически активных веществ поросятам 1-й опытной группе в дозе 15 г с 8-го по 15-й день и 20 г с 15-дневного возраста на протяжении всего эксперимента вызвало «перенаселение» организма бактериями и привело к угнетению биохимических показателей крови, что проявилось в снижении общего белка и $\gamma$-глобулиновой фракции, следовательно в угнетении естественной резистентности организма.

Завышение дозировки пробиотиков бактерий рода Bacillus штаммов бацилл B. subtillus и B. amyloliquefaciens в 1-й опытной группе также привело к повышению уровня глюкозы в крови молодняка на 2,1 ммоль/л $(P>0,95)$ и 2,6 ммоль/л $(P>0,99)$, следовательно к нарушению углеводного обмена.

Заключение. Применение биологически активных веществ оказывает положительное влияние на морфологические и биохимические показатели крови только при рациональном их использовании. Завышение дозировки (в дозе 15 г с 8-го по 15-й день и 20 г с 15-дневного возраста на протяжении всего эксперимента) и отсутствие схемы дачи препаратов привело к угнетению как морфологических, так и биохимических показателей крови.

Использование пробиотика

из расчета 5 г на 1 голову с 8-го по 15-й день, 10 г с 24-го по 28-й и с 35-го по 90-й день жизни (7 дней препарат получали, 5 дней перерыв) позволило улучшить окислительно-восстановительные процессы организма. Это произошло за счет повышения содержания гемоглобина в 90-дневном возрасте на 26,6 и 10,8 \% по сравнению со сверстниками 1-й опытной и контрольной групп, а также повышения общего белка и естественной резистентности молодняка за счет $\gamma$-глобулиновой фракции.

\section{СПИСОК ЛИТЕРАТУРЫ}

1. Бетин А.Н. Эффективность использования пробиотика «Био Плюс ҮС» - пять плюс поросят // Свиноводство. - 2016. - № 5. - С. 36-40.

2. Влияние биологически активных препаратов на рост поросят-сосунов / А.М. Гурьянов [и др.] // Межвуз. сб. науч. тр. Мордовского ун-та. - Саранск, 2001. - С. 167-169.

3. Оптимизация рационов кормления молодняка свиней в условиях Республики Мордовии / А.М. Гурьянов [и др.] // Аграрный научный журнал. - 2018. № 11. - С. 7-12.

4. Острикова Э.Е. Научно-практическое обоснование применения биологических препаратов в свиноводстве: автореф. дис. ... д-ра с.-х. наук. - Пос. Персиановский, 2012. - 46 с.

5. Полозюк О.Н., Колесников И.А., Полотовский К.А. Биологически активные вещества: как они влияют на биохимические показатели крови подсвинков // Свиноводство. - 2016. - № 5. - С. 74-75.

6. Buschman H.A. Selection auf immunologische Parameter - ein neuer Weg zur Zucht auf Krankheitsresistenz // Zuchtungskunde, 1982, Vol. 54, No. 4, P. 239-245.

Полозюк Ольга Николаевна, д-р биол. наук, проф. кафедры «Терапия и пропедевтика», Донской государственный аграрный университет. Россия.

346493, Ростовская обл., Октябрьский $p$-н, пос. Персиановский, ул. Кривошлькова, 24.

Тел.: (86360) 3-51-50.

Лапина Татьяна Ивановна, $\partial-p$ биол. наук, проф., ФГБУ «Ростовский референтный иеентр Россельхознадзора». Россия.

344034, г. Ростов-на-Дону, пер. Синявский, 21 В.

Тел.: (863) 224-13-38.

Ключевые слова: поросята; биодобавки; биохимические показатели крови; морфологчческие показатели крови; период доращивания.

\section{INFLUENCE OF DIETARY SUPPLEMENT ON THE BIOCHEMICAL INDICATORS OF PIGS' BLOOD DURING NURSERY}

Polozyuk Olga Nikolaevna, Doctor of Biological Sciences, Professor of the chair "Therapy and Propaedeutics", Don State Agrarian University. Russia.

Lapina Tatyana Ivanovna, Doctor of Biological Sciences, Professor, Rostov reference center of Rosselkhoznadzor. Russia.

Keywords: piglets; dietary supplement; blood biochemical parameters; morphological parameters of blood; nursery period.

It has been established that biologically active substances must be used at certain periods in the life of piglets and in certain dosages. The use of a probiotic based on bacteria of the
Bacillus of the B. subtillus and B. amyloliquefaciens bacilli strains at a rate of $20 \mathrm{~g}$ per head from the 8th to the 28th and from the 35th to 90th days of life caused "overpopulation" of the body of young animals with bacteria. It led to the inhibition of biochemical blood parameters. This consisted in a decrease in the total amount of protein and $\gamma$-globulin fraction, and in an increase in the level of glucose in the blood of piglets by 2.1 and $2.6 \mathrm{mmol} / \mathrm{L}$. Therefore, it led to a violation of protein and carbohydrate metabolism. Using a probiotic at the rate of $5 \mathrm{~g}$ per 1 head from the 8th to the 15th day, $10 \mathrm{~g}$ from the 24th to the 28th and from the 35th to the 90th day of life allowed improving the redox processes of the body. 